\title{
Recombinant Human Papillomavirus Nonavalent Vaccine
}

National Cancer Institute

\section{Source}

National Cancer Institute. Recombinant Human Papillomavirus Nonavalent Vaccine. NCI Thesaurus. Code C119664.

A non-infectious, recombinant, nonavalent vaccine prepared from hig hly purified virus-like particles (VLPS) comprised of the major capsid (L1) proteins from human papillomavirus (HPV) types $6,11,16,18,31,33,45,52$, and 58, with active immunizing activity. Upon administration, the recombinant HPV nonavalent vaccine activates the immune system to produce antibodies against the $9 \mathrm{HPV}$ types. This protects ag ainst HPV infection and HPV-related cancers. Altogether, HPV types 6, 11, 16, 18, 31, 33, 45, 52, and 58 account for the majority of the HPV types that cause cervical, vulvar, vaginal and anal cancers. 